\title{
Effect of Different Resource Conservation Practices on Soil Biological Properties and Biomass Production of Different Plant Parts of Soybean
}

\author{
Rathod Anju Vijaysing*, D.V. Mali, Tupaki Lokya, S.D. Jadhao, V.K. Kharche, \\ N.M. Konde and A.N. Paslawer
}

Department of Soil Science and Agriculture Chemistry, Dr. PDKV, Akola, India

*Corresponding author

\section{A B S T R A C T}

\section{Keywords}

Soil Microbial Biomass Carbon (SMBC), Soil Microbial Biomass Nitrogen (SMBN),

Biomass yield, Resource conservation

Article Info

Accepted:

17 July 2018

Available Online:

10 August 2018
The present investigation entitled, "Effect of different resource conservation practices on soil biological properties and biomass production of different plant parts of soybean" was undertaken during 2014-15 at Research farm, Dr. PDKV, Akola. The experiment was laid out in Randomized Block Design with nine treatments replicated three times. The treatments comprised of unfertilized control, chemical fertilizers alone and their combinations with organics viz., FYM and phosphocompost. The soil of experimental site was black belongs to Vertisols. The soil and plant samples were collected and analyzed for their different properties. The application of RDF based on soil test through FYM + remaining $\mathrm{P}$ through phosphocompost $(100 \% \mathrm{~N}$ through FYM $+\mathrm{P}$ compensation through phosphocompost to previous crop) recorded significantly highest soil microbial biomass carbon (SMBC) (232.36 mg kg-1) and microbial biomass nitrogen $\left(30.92 \mathrm{mg} \mathrm{kg}^{-1}\right)\left(\mathrm{T}_{7}\right)$. The maximum $\left(2776.73 \mathrm{~kg} \mathrm{ha}^{-1}\right)$ total biomass was noticed in treatment $\left(\mathrm{T}_{2}\right)$ where RDF based on soil test $(25 \% \mathrm{~N}$ through dhaincha lopping + RDF compensation to previous

\section{Introduction}

Soybean (Glycine max) is known as 'Golden bean' of $20^{\text {th }}$ century. It is the second largest oilseed crop in India after groundnut.

Among all agricultural crops soybean is most important crop for carbon sequestration because soybean forms mutualistic symbiosis with mycorrhizal fungi.

Mycorrizal fungi contributes in carbon sequestration as it has high constriction of fungal hyphae, the hyphal entanglement stabilizes soil aggregates which may stabilize organic matter against rapid decomposition. The hyphae of arbuscular mycorrhizal fungi produce the glycoprotein, glomalin which may combine with tannin like compound to form a very resistant form of organic matter, a slowly decomposing material.

Soybean builds up soil fertility by fixing a large amount of atmospheric nitrogen through its root nodules and also through leaf fall on the ground at maturity. It can be used as fodder, forage and can be made into hay, silage etc. Its forage and cake possess excellent nutritive value for livestock and poultry. 


\section{Materials and Methods}

The field experiment comprised of nine treatments with three replications in the Randomized Block Design (RBD) was conducted on cotton-soybean rotation.

The present experiment was superimposed on soybean during 2014-15.

The treatments comprised of RDF based on soil test (100\% RDF through only chemical fertilizers), RDF based on soil test $(25 \% \mathrm{~N}$ (through dhaincha lopping, composted cotton stalk, wheat, sorghum stubbles and neemcake), soil test based RDF through FYM + remaining $\mathrm{P}$ through phosphocompost (100\% N through FYM with compensation of $\mathrm{P}$ through phosphocompost), soil test based RDF through FYM + remaining $\mathrm{P}$ through phosphocompost (50\% N through FYM with compensation of N, P through phosphocompost and urea) and soil test based RDF through FYM + remaining $\mathrm{P}$ through phosphocompost $\quad(50 \quad \% \quad \mathrm{~N}$ through leucaenaloppings with compensation of $\mathrm{N}$ and $\mathrm{P}$ through phosphocompost and urea).

The experimental soil was Vertisol, having montmorillonitic mineralogy, alkaline in reaction with low available $\mathrm{N}$ and $\mathrm{P}$ and high in $\mathrm{K}$.

\section{Soil microbial biomass carbon}

Soil microbial biomass carbon was determined by chloroform fumigation extraction method as described by Jenkinson and Powlson (1976).

\section{Soil microbial biomass nitrogen}

Soil microbial biomass nitrogen was determined by Modified direct extraction method as described by Jenkinson and Ladd (1981).
Collection and preparation of Plant samples for analysis

\section{Root biomass}

Roots were taken after 85 days of sowing from a specific area $(0.20 \mathrm{~m} \times 0.20 \mathrm{~m})$ to a depth of $30 \mathrm{~cm}$ with a narrow flat bladed shovel and hand saw. Root sample were passed through a series of sieves to collect the coarse roots ( $>4$ $\mathrm{mm})$, medium roots $(2-4 \mathrm{~mm})$ and fine roots $(0.50-1 \mathrm{~mm})$ without attempting to differentiate live and dead roots. Roots were dried at $65{ }^{\circ} \mathrm{C}$ at a constant temperature.

\section{Leaf litter biomass}

Leaf litter was collected from $1 \mathrm{~m}^{2}$ area between the two rows. The samples were collected by hand on nylon net at 65 days and after harvest of the crop.

The leaf litter sample were cleaned with tap water and dried at $65{ }^{\circ} \mathrm{C}$.

\section{Rhizodeposition biomass}

Carbon content in rhizodeposition from root exudates were assumed $10 \%$ of above ground harvestable biomass of soybean. (Kundu et al., 2008 and Shamoot et al., 1968).

\section{Nodule count and biomass}

Nodules count has taken at flowering stage, cleaned with tap water and dried at $65{ }^{\circ} \mathrm{C}$.

\section{Grain and Straw biomass}

The straw were collected at harvested stage and dried at $65{ }^{\circ} \mathrm{C}$.

\section{Statistical analysis}

The data on different parameters were tabulated and analyzed statistically by the 
methods described by Panse and Sukhatme (1971).

\section{Results and Discussion}

Effect of different resource conservation practices on soil biological properties

\section{Soil microbial biomass carbon}

Data pertaining to soil microbial biomass carbon (SMBC) as influenced by different treatments are presented in Table 1. The significantly highest soil microbial biomass carbon $\left(232.36 \mathrm{mg} \mathrm{kg}^{-1}\right)$ was recorded with the application of RDF based on soil test through FYM + phosphocompost $(100 \% \mathrm{~N}$ through FYM and compensation of $\mathrm{PC}$ to previous crop) i.e. $\mathrm{T}_{7}$. This might be due to the supply of additional mineralizable and readily hydrolysable $\mathrm{C}$ due to organic matter application resulted in higher microbial activity and in turn higher microbial biomass carbon. The lowest soil microbial biomass carbon was observed under the application of RDF based on soil test (recommended dose of fertilizer to previous crop) i.e. $\mathrm{T}_{1}(155.89 \mathrm{mg}$ $\left.\mathrm{kg}^{-1}\right)$. Similar observations were recorded by Manna et al., (1996) and Verma and Mathur (2009).

Kanazawa et al., (1988) reported that soil microbial biomass carbon was largest with the use of FYM, followed by chemical fertilizer treated plot and smallest in the control. The similar findings were also noted bySaran et al., (1996) and Saini et al., (2005).

\section{Soil microbial biomass nitrogen}

Data pertaining to soil microbial biomass nitrogen (SMBN) as influenced by different treatments are presented in Table 1. The significantly highest soil microbial biomass nitrogen $\left(30.92 \mathrm{mg} \mathrm{kg}^{-1}\right.$ ) was observed with the application of RDF based on soil test through FYM + phosphocompost $(100 \% \mathrm{~N}$ through FYM and compensation of $\mathrm{PC}$ to previous crop) $\left(\mathrm{T}_{7}\right)$. The lowest soil microbial biomass carbon was observed under the application of RDF based on soil test (recommended dose of fertilizer to previous crop) i.e. $\mathrm{T}_{1}\left(20.12 \mathrm{mg} \mathrm{kg}^{-1}\right)$.

The soil microbial biomass nitrogen was markedly decreased under RDF based on soil test. Application of organics in combination with inorganic fertilizers resulted in significantly highest soil microbial biomass nitrogen (SMBN) as compared to rest of the treatments.

High soil organic carbon, more root incorporation and additional supply of nitrogen through FYM to the microrganisms, might be the reason for improving microbial biomass nitrogen. The results are in close agreement with earlier finding of Kaur et al., (2005) and Verma and Mathur (2009)

Effect of different resource conservation practices on biomass yield of different plant parts of soybean

The data related to total biomass to the soil through soybean is presented in Table 2 . Application of RDF based on soil test (25\% N through dhaincha lopping + RDF compensation to previous crop) i.e. $\mathrm{T}_{2}$ indicate a higher value of gross biomass to the soil by all plant parts leaf, root, nodule and rhizodeposits by soybean.

Soybean straw assimilated $1550.83 \quad \mathrm{~kg}$ biomass $\mathrm{ha}^{-1}$ with application of RDF based on soil test $(25 \% \mathrm{~N}$ through dhaincha lopping + RDF compensation to previous crop) $\left(\mathrm{T}_{2}\right)$, followed by the treatments $\mathrm{T}_{7}(1504.65 \mathrm{~kg}$ $\left.\mathrm{ha}^{-1}\right), \mathrm{T}_{9}\left(1423.63 \mathrm{~kg} \mathrm{ha}^{-1}\right), \mathrm{T}_{1}(1388.96 \mathrm{~kg}$ $\left.\mathrm{ha}^{-1}\right), \mathrm{T}_{6}\left(1380.30 \mathrm{~kg} \mathrm{ha}^{-1}\right)$, and $\mathrm{T}_{3}(1377.31 \mathrm{~kg}$ $\mathrm{ha}^{-1}$ ) which were at par with each other. 
Table.1 Effect of different resource conservation practices on biological properties of soil

\begin{tabular}{|c|c|c|c|c|}
\hline \multirow[t]{3}{*}{ Tr. } & \multicolumn{2}{|l|}{ Rotation } & \multirow{3}{*}{$\begin{array}{c}\mathrm{SMBC} \\
\left(\mathrm{mg} \mathrm{kg}^{-1}\right)\end{array}$} & \multirow{3}{*}{$\begin{aligned} \text { SMBN } \\
\left(\mathrm{mg} \mathrm{kg}^{-1}\right)\end{aligned}$} \\
\hline & Cotton & Soybean* & & \\
\hline & \multicolumn{2}{|l|}{ Treatment details } & & \\
\hline$T_{1}$ & RDF & RDF & 155.89 & 20.12 \\
\hline$T_{2}$ & $25 \% \mathrm{~N}$ (Dhaincha loppings) + RDF compensation & RDF & 187.82 & 24.08 \\
\hline $\mathbf{T}_{3}$ & $25 \% \mathrm{~N}$ (Cotton stalk) composted + RDF compensation & RDF & 168.79 & 22.10 \\
\hline$T_{4}$ & $25 \% \mathrm{~N}$ (Wheat straw) + RDF compensation & $\mathrm{RDF}$ & 192.34 & 25.11 \\
\hline$T_{5}$ & $25 \% \mathrm{~N}$ (Bio mulch)+ RDF compensation & RDF & 198.40 & 26.75 \\
\hline$T_{6}$ & $25 \% \mathrm{~N}$ (Neemcake) + RDF compensation & RDF & 202.36 & 28.90 \\
\hline$\overline{T_{7}}$ & $100 \% \mathrm{~N}(\mathrm{FYM})+$ compensation of $\mathrm{P}$ (phosphocompost) & $\mathrm{RDF}+\mathrm{PC}$ & 232.36 & 30.92 \\
\hline $\mathrm{sT}_{8}$ & $\begin{array}{l}50 \% \mathrm{~N}(\mathrm{FYM})+\mathrm{P} \text { compensation (phosphocompost) }+\mathrm{N} \\
\text { compensation (Urea) }\end{array}$ & $\mathrm{RDF}+\mathrm{PC}$ & 215.70 & 29.43 \\
\hline \multirow[t]{3}{*}{$\mathrm{T}_{9}$} & $\begin{array}{l}50 \% \mathrm{~N} \text { (Leucaenaloppings) + P compensation } \\
\text { (phosphocompost) + N compensation (Urea) }\end{array}$ & $\mathrm{RDF}+\mathrm{PC}$ & 210.26 & 29.18 \\
\hline & \multicolumn{2}{|l|}{$\mathrm{SE}(\mathrm{m}) \pm$} & 1.14 & 0.29 \\
\hline & \multicolumn{2}{|l|}{ CD at $5 \%$} & 3.41 & 0.87 \\
\hline
\end{tabular}

$* \mathrm{~T}_{1}-\mathrm{T}_{6}$ : RDF based on soil test

$\mathrm{T}_{7}-\mathrm{T}_{9}$ : RDF based on soil test through FYM + remaining $\mathrm{P}$ through phosphocompost.

Table.2 Effect of different resource conservation practices on biomass yield of different plant parts of soybean

\begin{tabular}{|c|c|c|c|c|c|c|c|c|}
\hline \multirow[t]{4}{*}{$\operatorname{Tr}$} & \multirow{2}{*}{\multicolumn{2}{|c|}{ Rotation }} & \multicolumn{5}{|c|}{ Biomass $\left(\mathrm{kg} \mathrm{ha}^{-1}\right)$} & \multirow{4}{*}{$\begin{array}{c}\text { Total } \\
\text { biomass } \\
\left(\mathrm{kg} \mathrm{ha}^{-1}\right)\end{array}$} \\
\hline & & & \multirow[t]{3}{*}{ straw } & \multirow{3}{*}{$\begin{array}{l}\text { Leaf } \\
\text { litter }\end{array}$} & \multirow[t]{3}{*}{ Roots } & \multirow[t]{3}{*}{ Nodules } & \multirow{3}{*}{$\begin{array}{c}\text { Rhizo } \\
\text { Deposit } \\
\text { ion }\end{array}$} & \\
\hline & Cotton & Soybean* & & & & & & \\
\hline & \multicolumn{2}{|l|}{ Treatment details } & & & & & & \\
\hline $\mathrm{T}_{1}$ & RDF & RDF & 1388.96 & 448.54 & 298.38 & 67.63 & 183.75 & 2387.25 \\
\hline $\mathrm{T}_{2}$ & $\begin{array}{l}25 \% \mathrm{~N} \text { (Dhaincha loppings) + } \\
\text { RDF compensation }\end{array}$ & $\mathrm{RDF}$ & 1550.83 & 533.24 & 391.63 & 92.63 & 208.41 & 2776.73 \\
\hline $\mathrm{T}_{3}$ & $\begin{array}{l}25 \% \mathrm{~N} \text { (Cotton stalk) composted } \\
+\mathrm{RDF} \text { compensation }\end{array}$ & RDF & 1377.31 & 400.90 & 285.00 & 57.37 & 177.82 & 2298.41 \\
\hline $\mathrm{T}_{4}$ & $\begin{array}{l}25 \% \mathrm{~N} \text { (Wheat straw) + RDF } \\
\text { compensation }\end{array}$ & $\mathrm{RDF}$ & 1296.30 & 301.74 & 222.20 & 53.06 & 159.80 & 2033.10 \\
\hline $\mathrm{T}_{5}$ & $\begin{array}{l}25 \% \mathrm{~N} \text { (Bio mulch)+ RDF } \\
\text { compensation }\end{array}$ & RDF & 1174.67 & 270.27 & 205.18 & 51.67 & 144.49 & 1846.27 \\
\hline $\mathrm{T}_{6}$ & $\begin{array}{l}25 \% \mathrm{~N}(\text { Neemcake })+\mathrm{RDF} \\
\text { compensation }\end{array}$ & $\mathrm{RDF}$ & 1380.30 & 411.04 & 306.33 & 62.97 & 179.13 & 2339.76 \\
\hline $\mathrm{T}_{7}$ & $\begin{array}{l}100 \% \mathrm{~N}(\mathrm{FYM})+\text { compensation } \\
\text { of P (phosphocompost) }\end{array}$ & $\mathrm{RDF}+\mathrm{PC}$ & 1504.65 & 516.68 & 377.60 & 82.46 & 202.13 & 2683.52 \\
\hline $\mathrm{T}_{8}$ & $\begin{array}{l}50 \% \mathrm{~N}(\mathrm{FYM})+\mathrm{P} \\
\text { compensation (phosphocompost) } \\
+\mathrm{N} \text { compensation (Urea) }\end{array}$ & $\mathrm{RDF}+\mathrm{PC}$ & 1319.44 & 397.83 & 280.50 & 57.27 & 171.73 & 2226.77 \\
\hline $\mathrm{T}_{9}$ & $\begin{array}{l}50 \% \mathrm{~N} \text { (Leucaenaloppings) + P } \\
\text { compensation (phosphocompost) } \\
+\mathrm{N} \text { compensation (Urea) }\end{array}$ & $\mathrm{RDF}+\mathrm{PC}$ & 1423.63 & 457.13 & 313.15 & 70.60 & 188.08 & 2452.58 \\
\hline & $\mathrm{SE}(\mathrm{m}) \pm$ & & 62.22 & 40.62 & 13.47 & 4.46 & 5.69 & 60.86 \\
\hline & $\mathrm{CD}$ at $5 \%$ & & 186.54 & 121.77 & 40.39 & 13.37 & 17.06 & 182.45 \\
\hline
\end{tabular}

* $\mathrm{T}_{1}-\mathrm{T}_{6}$ : RDF based on soil test

$\mathrm{T}_{7}-\mathrm{T}_{9}$ : RDF based on soil test through FYM + remaining P through phosphocompost. 
Similar trend was also found in respect of carbon input through root, nodule and rhizodeposition. The application of RDF based on soil test $(25 \% \mathrm{~N}$ through dhaincha lopping + RDF compensation $\left(\mathrm{T}_{2}\right)$ resulted improvement in biomass production in different plant parts of soybean. The biomass was recorded the extent of 533.24, 391.63, $92.63,208.41 \mathrm{~kg} \mathrm{ha}^{-1}$ respectively leaf litter, roots, nodule and rhizodeposition. As a result, total biomass production was improved respectively in the same treatment.

The maximum $\left(2776.73 \mathrm{~kg} \mathrm{ha}^{-1}\right)$ total biomass was noticed in treatment $\left(\mathrm{T}_{2}\right)$ where RDF based on soil test $(25 \% \mathrm{~N}$ through dhaincha lopping + RDF compensation to previous crop) followed by treatment $\mathrm{T}_{7}(2683.52 \mathrm{~kg}$ $\left.\mathrm{ha}^{-1}\right)$. However, these treatments were found at par with each other. The application of $25 \%$ $\mathrm{N}$ through bio mulch and compensation of RDF resulted substantial decline in the total biomass $\left(1846.27 \mathrm{~kg}\right.$ ha $\left.^{-1}\right)$ i.e.T . An additional contribution of carbon was also made by soybean through leaf, root, nodule and rhizodeposition biomass. The results are in conformity with findings of Kundu et al., (2008).

\section{Soil microbial biomass carbon}

The soil microbial biomass carbon was assessed and it was ranged from 155.89 to $232.36 \mathrm{mg} \mathrm{kg}^{-1}$ of soil at the harvest of soybean. Among various treatments, $\mathrm{T}_{7}[\mathrm{RDF}$ based on soil test through FYM + remaining $\mathrm{P}$ through phosphocompost $(100 \% \mathrm{~N}$ through $\mathrm{FYM}+$ compensation of through phosphocompost to previous crop)] recorded significantly higher value of SMBC followed by treatment $\mathrm{T}_{8}$ [RDF based on soil test through $\mathrm{FYM}+$ remaining $\mathrm{P}$ through phosphocompost (50\% $\mathrm{N}$ through FYM $+\mathrm{P}$ compensation through phosphocompost $+\mathrm{N}$ compensation through urea recommended dose of fertilizer to previous crop)].All the sources of organics (FYM and Phosphocompost) were found beneficial in improving soil microbial biomass carbon.

\section{Soil microbial biomass nitrogen}

The application of RDF based on soil test through $\mathrm{FYM}+$ remaining $\mathrm{P}$ through phosphocompost (100\% N through FYM + P compensation through phosphocompost to previous crop) recorded significantly highest microbial biomass nitrogen $\left(30.92 \mathrm{mg} \mathrm{kg}^{-1}\right.$ ) $\left(\mathrm{T}_{7}\right)$ followed by RDF based on soil test through $\mathrm{FYM}+$ remaining $\mathrm{P}$ through phosphocompost $(50 \% \mathrm{~N}$ through FYM $+\mathrm{P}$ compensation through phosphocompost $+\mathrm{N}$ compensation through urea to previous crop) i.e. $\mathrm{T}_{8}\left(29.43 \mathrm{mg} \mathrm{kg}^{-1}\right)$ in soil. The lowest value of SMBN i.e. $\mathrm{T}_{1}\left(20.12 \mathrm{mg} \mathrm{kg}^{-1}\right)$ with was recorded the application of RDF based on soil test.

\section{Biomass to the soil through soybean}

Application of RDF based on soil test $(25 \% \mathrm{~N}$ through dhaincha + RDF compensation to previous crop) $\left(\mathrm{T}_{2}\right)$, indicated a higher value of biomass to the soil by all plant parts like leaf, root, nodule and rhizo deposits by soybean. The maximum (2776.73 $\left.\mathrm{kg} \mathrm{ha}^{-1}\right)$ total carbon input was noticed in treatment $\left(\mathrm{T}_{2}\right)$ where RDF based on soil test $(25 \% \mathrm{~N}$ through dhaincha + RDF compensation to previous crop) while it was $1846.27 \mathrm{~kg} \mathrm{ha}^{-1}$ in RDF based on soil test $(25 \% \mathrm{~N}$ through bio mulch + RDF compensation).

\section{References}

Jenkinson, D. S. and D. S. Powlson, 1976. The effect of biocidal treatments on metabolism in soil- V.A. method for measuring soil biomass. Soil Biol. Biochem. 8: 209-213.

Jenkinson, D. S. and J. N. Ladd, 1981. Microbial biomass in soil: measurement 
and turnover in. Soil Biochem. 5: 415471.

Kaur, K., K. K. Kapoor and A. P. Gupta, 2005. Impact of organic manures with and without mineral fertilizers on soil chemical and biological properties under tropical conditions. J. Plant Nutr. Soil Sci. 168: 117-122.

Kundu, S., R. Bhattacharya, V. Prakash and H. S. Gupta, 2008. Carbon sequestration potential of Inceptisols under long term soybean-wheat rotation in Subtemperate rainfed agro-ecosystem of North-Waste Himalayas. J. Indian Soc. Soil Sci. 56(4): 423-429.

Manna, M. C., S. Kundu, M. Singh and P. N. Takkar, 1996. Influence of FYM on dynamics of microbial biomass and its turnover and activity of enzymes under a soybean - wheat system on a Typic Haplustert. J. Indian Soc. Soil Sci. 44(3): 409-412.

Panse, V. G. and P. V. Sukhatme, 1971. Statistical Methods for Agricultural Workers. ICAR, New Delhi.
Saini, V. K., S. C. Bhandari, S. K. Sharma and S. C. Tarafdar, 2005. Assessment of microbial biomass under integrated nutrient management in soybean winter maize cropping sequences. J. Indian Soc. Soil Sci. 53(3): 346-351.

Saran, R. N., R. A. Shama, S. P. Wani, P. Pathak and G. Alagarswamy, 1996. Nutrient management in Vertisols, Indon: Pages 24-28 In Progress ISP3 research at benchmark srtes in Asia: Proceedings of a Regronal Workshop, 15-16 Apr 1996.

Shamoot, S. O., L. McDonald and W. V. Bartholomew, 1968. Rhizodeposition of organic debris in Soil. Soil Sci. Society of America Proceedings 32: 817-820.

Verma, G. and A. K. Mathur, 2009. Effect of integrated nutrient management system on active pool of soil organic matter under maize wheat system of a Typic Haplustept. J. of Indian Soc. Soil Sci. 57(3): 317-322.

\section{How to cite this article:}

Rathod Anju Vijaysing, D.V. Mali, Tupaki Lokya, S.D. Jadhao, V.K. Kharche, N.M. Konde and Paslawer, A.N. 2018. Effect of Different Resource Conservation Practices on Soil Biological Properties and Biomass Production of Different Plant Parts of Soybean. Int.J.Curr.Microbiol.App.Sci. 7(08): 2941-2946. doi: https://doi.org/10.20546/ijcmas.2018.708.312 